Grzegorz Radomski

Nicolaus Copernicus University in Toruń (Poland)

\title{
The Self-government Constitutes an Essential Element of the Civil Security in Polish Political Thought after 1989
}

\begin{abstract}
The article analyses the Polish political thought after 1989 concerning the local self-government. Attention was drawn to various currents of the Polish political thought, such as liberalism, conservatism, the teaching of the Church, social democracy or nationalism. Particular attention was paid to the role of the self-government in building civil society and to the forms of citizen participation. According to the main hypothesis, the activity of the local self-government is generally accepted. The self-government is an important element of political projects and is considered an important element of civil security and plays an important role in building the civil society. The thought of Charles Taylor "the atrophy of the self-government constitutes a danger for the stability of the liberal society and in the consequence for the freedom protected by it" suited undoubtedly the liberals and the representatives of other political trends
\end{abstract}

Keywords: self-government, civil society, political thought, civil security, participation

\section{Introduction}

The purpose of the article is to analyze the Polish political thought after 1989 in regard to the local self-government. The starting point is the conviction that the self-government constitutes an essential element of the civil security. This last statement was created by a priest, Jan Krucina. The analysis includes the main ideological trends such as conservatism, liberalism, nationalism, social democracy as well as the anti-system thought and the concepts of the National Revival of Poland or alter-globalist and monarchist groups. Particular attention is paid to urban movements and due to the importance of subsidiarity to the concepts which started to exist within the social science of the Church. 
The basic sources include the programmes of political parties, election manifestos, press statements, memoires and letters. The catalogue of sources is extended by statements in form of blogs, comments, etc.

The main research question is following: did the local self-government limit the omnipotence of the authoritarian state and favor the democratization after the year 1989? Creators of the Polish political thought, while referring to de Tocqueville, searched after the year 1989 for effective ways to put the institution of practical learning and practicing democracy into operation again. The new manner of organizing the state was connected with the slogan of rebuilding social bonds at the local level which was integrally connected with strengthening of the self-government institutions. The purpose of its restitution was at the same time to enable the legitimization of a new political order. This question raised much less emotions in the political discourse than the de-communization, abortion, lustration or even the position of a head of the state or electoral law. The assessment formulated after the parliamentary elections of the year 1991 may be generalized: "The self-government ideas which were good as the weapon in the fight against the remains of the etatistic communism turned out, especially for the solidarity parties, to be less catchy in the fight for gaining votes in the elections" (Gieorgica, 1991, pp. 3-4). It did not mean, however, the lack of interest in the self-government policy. Additionally, since the self-government has been one of the elements of the democratic state in the West of Europe, it constituted one of the arguments for the benefit of introducing of this solution in Poland. Similarly important were the Polish historical experiences and the observation of transformations that took place in European states which entered earlier the way of democratization. It has been seen that the decentralization itself caused the increase of the economic effectivity and the social development in Spain. Therefore, it should not be surprising that the first legislative initiative of the revived Senate which was dominated by the "Solidarity" activists was pointing to the need of the reconstruction of the authentic self-governance. It was even recognized that the introduction of the self-government was a guarantee of the safety of transformations (Olszewski, 2007, pp. 20-22).

The opinion of the senator Andrzej Stelmachowski was quoted who said that the introduction of the self-government laws would strengthen the democracy at the bottom and if the whirlwind of history wanted to stop it to change the ongoing processes it would for sure oppose to it. Tadeusz Mazowiecki designated for the first non-communist prime minister perceived the necessity to build a state which was about to create "safe frames for individual and collective existence". He recognized the creation of an authentic self-government as an extremely important issue. In one of speeches at the Polish parliament in 1990 he said: "Until we create a real self-government, we will not defeat the resistance that we meet when we introduce changes. We have to part the outdated and inefficient structures which are not able to trigger the social initiative" (Rok rzadu premiera Mazowieckiego, 1990, p. 33). In another one he argued: "The real local self-government will constitute a strong foundation which makes it possible to build the further fragments of the construction of 
the state sovereignty, where the whole power comes from the nation" (Rok rzadu premiera Mazowieckiego, 1990, p. 46).

\section{Self-government in Polish Political Thought}

The determination of axiological bases of restoration and development of the self-governance has been recognized as essential. Apart from freedom, attention is paid to ideas of the common weal or solidarity and equality (Ganowicz, 2014, pp. 62-63). In the last-mentioned case this demand is used contemporarily to increase the role of women in the self-government. The Liberals stressed that the citizen is not only a customer who demands to be served quickly by the administration, but also co-responsible for the administration. Irena Lipowicz proved: "We know that we once introduced the self-government in order that the intimidated local Poland, used to the government of party caciques from the Polish United Worker's Party raises at last the head, takes a breath and starts to think about its area. We are a country which is wounded by the too-long totalitarian period" (Lipowicz, 2009, p. 148). It seems that the majority of Polish journalists and politicians would be willing to accept the statement of Jerzy Buzek: "From the triangle democracy - local self-government - society one cannot take out anything. The democracy are not only free elections but also self-governance". Pronouncements have been made since 2015. In particular, it was stressed that "defending the idea of the self-government and self-governance is our primary duty" Kazimierz Michał Ujazdowski also stated precisely that mistrust of local self-governments would reduce the possibility of modernizing Poland.

It is assumed as the research hypothesis that the majority of political trends perceived the possibility to transform the citizens from observers into participants. With other words the self-government was regarded as an institution creating the situation which would require from citizens activities forcing to acquire specific skills. In the consequence, in the research field there will be questions regarding the reception of the idea of the deliberative democracy and communitarian threads. I also assume that although the notions regarding the selfgovernment evolve due to the adaptation of the proposal of the increased participation, the reference point are still, however, the classical political doctrines and notions worked out at the turn of $19^{\text {th }}$ and $20^{\text {th }}$ Century. The broad participation was also definitely supported while the importance of responsiveness was stressed. The thought of Charles Taylor "the atrophy of the self-government constitutes a danger for the stability of the liberal society and in the consequence for the freedom protected by it" (Taylor, 1996, p. 40) suited undoubtedly the liberals and the representatives of other political trends.

In one of the publications of the Christian Democratic Movement it was added: "Any social processes and structures should be suitable for a human being. They should serve him. They cannot be against him, harm his development". Let us show as an example that in the manifesto of the Conservative Coalition published on 20 March 1994 it was written: "We did not get rid of communism to maintain its flaw - individualism which hinders the individual 
initiative". It was stated in the Appeal of participants of the $22^{\text {nd }}$ Pilgrimage of the Local Self-Government to Jasna Góra: "The local self-government is one of the first schools of the common weal, a school that leads to the empowerment of local communities". The vision of a system based on relations of balance between the state and the self-government was present in the programme of groups referring to agrarianism (Klimek, 2013).

In the draft Constitution prepared jointly by the Polish Peasants' Party and the Labor Union in 1994 it was stated that: "The Republic of Poland guarantees the participation of the local self-government in the exercise of public authority and the freedom of action of other forms of self-government" (Chruściak, 1997, p. 187). A separate chapter has been devoted to the self-government in the draft. During the Congress of 2007, the Peasants from the Polish Peasants' Party (PSL) claimed that the self-government should be the basis on which Poland of the $21^{\text {st }}$ century can be built. When defining the relations between the central and self-government administration, they stressed the need for the latter to be independent. The Centre was supposed to deal with national issues, while the self-government was supposed to deal with local issues. The introduction of self-government was in line with the ideas of national circles, according to which the authorities are to be only executors of the nation's decisions. The programme of the League of Polish Families, one of the groups of the current, states: "Self-governments give a sense of what it means to enjoy freedom in which everyone participates and in which everyone benefits" (Koziełło, 292, p. 229).

And the Liberals in turn referred to the idea of the civil state. Lech Mażewski argued in the year 1991: "As a matter of fact, an ideal of Liberals is the strong power, however, the one which is clearly limited and balanced. And this is possible by strengthening of the local selfgovernance and regionalization of Poland" (Mażewski, 1989, p. 16). In Political Review (pl. Przeglad Polityczny) Jan Hartman presented the role of the self-government in the concept of the minimum state in a model way. He wrote: "We are in favor of a typically liberal concept of the "drying nut tree" - a state which strengthens and facilitates itself by transferring its prerogatives and functions to other entities, especially those acting locally (the state which hardens when it shrinks - in such a way like the drying nut tree") (Hartman, 2002, p. 8). Also, in the political concepts of the social democratic movement or even anti-democratic environments a meaningful role was devoted to the self-government. For the Democratic Left Alliance, the idea of the deliberative democracy was important. It was stressed that political decisions are taken in the process of discussion carried out by free and equal citizens. The point of view of residents regarding a specific issue was about to be modified at the time of deliberation. In the course of debate the common weal will be worked out. Indeed, the weaknesses of the deliberation were perceived which according to the opinion of Chantal Mouffe weakens the pluralism, however the debate at the self-government level was accepted. In opinion of the Democratic Left Alliance exactly in the self-government the democracy based on dialogue may be realized.

In the opinion of animators of new urban movements, in Poland persists a belief that a strong civil society is a threat and not a chance for democracy. In its proposals the associa- 
tion Citizens in the Self-Government paid attention to the opening of the self-government decision process towards citizens by the compulsory introduction of social consultations when adopting the budget of the municipality. The lowering of the threshold of the number of required signatures under the draft of referendum as well as the introduction of the mandatory participatory budget were suggested. Similar statements could have earlier been found in the demands of the Democratic Party stressing that the quality of democracy is reflected first of all by the participation in the dialogue and social consultancy. The society becomes a partner of the authority. It is, however, possible only as the effect of strengthening of civil attitudes: "development of appropriate habits which allow people to use better their own abilities and instruments" (Karnowska, 2011, p. 227). An inspiration for the programme constituted the thoughts of Krzysztof Nawratek, the author of the concept of the plug-in citizen (Nawratek, 2008, p. 266).

It was also added that the self-government as a tool for building the civil society requires, however, the "high level of local elites or strong control system" (Mazowiecki, p. 344). Additionally, in the opinion of leaders of urban movements, the self-governments should be apolitical. The idea of participatory democracy through the local self-government, which was supposed to prove its worth in Porto Alegre in southern Brazil, was a point of reference for the alterglobalist community (Górski, 2003,pp. 8-40). Clarifying its essence Rafał Górski wrote: "The participatory democracy is a kind of compromise between supporters of direct democracy and defenders of representative democracy. In the cities where it was introduced, the local administration ceases to govern and is increasingly serving the community. Unnecessary authoritarian hierarchies and structures are slowly being eliminated, while (...) freedom and democratic choice are being broadened. In this way, people themselves start to manage matters that really affect their lives, even if they participate in elections" (Górski, 2007, p. 43). It was to be implemented by the self-government, understood as independent management of local affairs by the residents themselves (Górski, 2007, p. 53). In direct democracy a citizen acts individually because a participant of a referendum is somehow alone without the possibility of direct participation in the discussion. His views are therefore not shaped by a dialogue. In addition, a minority loses everything after a defeat and there is no a reasonable boundary drawn between the powers of a democratic community and the right of independence of individuals. Also worrying are experiences of direct democracy in traditional societies, e.g. in India, where gatherings of the general population of the village, who were given the right to rule, led to local despotism comparable to state totalism (Górski, 2007, p. 57). For example, by means of a demonstration effect - i.e. the possibility of perceiving one's own impact on a specific budget and participating in it - a participatory democracy can avoid the following dangers.

Among many proposals, attention should be paid to the attempts to use the potential of self-government officials in the work of political institutions, including parliament. It is worth recalling that the idea of a self-government chamber as an important element of Polish bicameralism has been present in Polish political thought since the interwar period. Post-1989 
demands can be grouped as follows: a) the concept of the self-government chamber with competence similar to the Senate or amended; b) a concept for changing the way in which members of the Senate are elected, considering the role of the self-government; c) increase in cooperation between the Senate and the-self-government without significant political changes. The concept of the Senate as the Self-Government Chamber was initially present in the system demands submitted by expert circles and groups referring to the interwar traditions and concepts proposed at the first meeting of the Solidarity Trade Union. It was also treated as yet another civil structure strengthening the subjectivity of society and a body aggregating the will of citizens. It was associated with the perceived weakness of political parties and the search for a new formula for transferring the influence of the sovereign nation on the state. Over time, the possibility of using it as an apolitical institution, an expert institution limiting the influence of political parties on public authority, was emphasized. In the opinion of some commentators, parties have become cartels independent of citizens. However, the concept of the Self-Government Chamber never took a definite form and other groups have not attempted to implement it, apart from the PSL. The idea was rather a contribution to the discussion on the legitimacy of the existence of bicameralism. However, the concept itself did not disappear from the public debate and was most often raised, which seems understandable, by the circles seeking to change the existing constitutional status quo (Radomski, 2017, p. 196).

\section{Civil Society as a Security Instrument}

In the Polish political thought, civil society was considered an important element of ensuring civil security. Even those who rejected these ideas stressed the need for citizens to participate in governments on the basis of the Republican idea.

One value connected with the local self-government was also the civil society which according to Ch. Taylor (1994, p. 59) may be defined in three different ways: 1) the civil society exists everywhere where there is room for the existence of free associations that are not controlled by the state; 2) civil society refers only to the situation in which society as a whole is able to organize and coordinate its activities without state supervision; 3 ) the civil society may be understood as a network of associations which are able to significantly influence current state policies or may even produce a change to state policy. Without going into interpretation disputes, one can assume according to Wiesław Bokajła that when we talk about the civil society we think of the society in which a group of institutions and different types of voluntary spontaneous organizations, unions and associations constitutes a basis of independent development of the citizen, free from the state intervention and constitutes at the same time the expression of their own activity, initiatives and needs" (Bokajło, 1998, p. 373).

It is worth remembering that in the half of the $19^{\text {th }}$ Century it was noticed that exactly in the municipality the civil virtue is developed since the community is so small that con- 
nections between their members are direct (Malewska-Szałgynia, 2002,p. 17). The hope for spurring of the civil activity and gaining of the skills of judicious use of civil freedoms was connected with the development of the self-governance. An important place was also given for the trust, loyalty and local identity. The important role in fulfilling of the democratic ideals which includes going from philosophical foundations to the practice was indicated. The sentence of A. de Tocqueville was adopted universally: "Nevertheless local assemblies of citizens constitute the strength of free nations. Town-meetings are to liberty what primary schools are to science; they bring it within the people's reach, they teach men how to use and how to enjoy it. A nation may establish a system of free government, but without the spirit of municipal institutions it cannot have the spirit of liberty" (de Tocquville, 1996, p. 61). The idea of the civil society was reflected in the best way in concepts of the broadly understood liberal environment. The statement: "There exist no well-functioning, modern civil society without a well-functioning institutional self-governance" (Imiołczyk, Regulski, pp. 8-9) may be regarded as representative. In the papers of "Political Review", one could find the statement that the civil society can be perceived as a certain form of realization of the ideal of the "Self-Governed Republic". The author of the article added: "I belong to those who regard the local self-government as an essential element of the civil society" (Sciciński, 1996, p. 87-89). It was indicated that the problem isn't whether someone is or isn't familiar with the local self-government, but it is rather connected with whether the individual feels the aspirations and the willingness to co-participate in the public management in order not to be managed but to be the co-managing individual. The participation is not only a vote for well-known persons. The citizen is not a human-being accepting even the best solutions coming from others but a person co-participating in creating of the local reality. Marek Sowa wrote: "The civil society are not only specific actions or initiatives. This is also and rather first of all the system, state of mind and the way of perception of the surrounding reality. The role of the self-government is to activate such attitudes" (Sowa, 2011, p. 414). The potential was seen first of all in the possibility to transform citizens from observers into participants. Julia Pitera indicated that the efficient management of the municipality does not consist in balancing of the budget at the end of the year, since municipality is not an enterprise.

The efficient management consists in stimulating of the activity of residents by creating different motivation mechanisms. A good summary that specifies the role of the civil society can be the observations published in the journal "Znak": "Besides, if the target of the self-government were only efficiency and effectiveness, the local communities would employ private corporations to realize their issues. But here it's about the political credibility of the local leadership, which does not come down to election markets" (Bukowski, 2011, p. 151). The statement of Michał Kulesza may be regarded as representative: "It depends on the self-government today whether it is possible to build the civil society in order that it controls the management structures and thus protects us from alienation of the authorities. There are big armies of regional civil servants in Poland who understand 
that the development today takes place in the municipality or in district and not only in Warsaw. And this is a hope" (Kulesza, 2008, p. 350). The Liberals stressed that the citizen is not only a customer who demands to be served quickly by the administration, but is also co-responsible for the administration. In the programme of the liberal party Civil Platform (pl.Platforma Obywatelska) it is noted: "such a programme should (...) spur to the abrupt increase of the civil activity and use of the huge development potential" (Karnowska, 2011, p. 155). The decentralization was justified as follows: "the decentralization is not only an act of good will of the central power, but it becomes a necessary, civilization condition for the proper management of public issues and effective care for the Polish national interest” (Karnowska, 2011, p. 155). The President of Gdańsk Paweł Adamowicz referred to a similar argumentation as he once wrote: "The self-government and the state should learn to cooperate with active citizens, to perceive and appreciate their bottom, innovation efforts" (Adamowicz, 2008, p. 73). The self-government was regarded most often as a school of civil education.

The President Aleksander Kwaśniewski wrote in a letter to the participants of the $1^{\text {st }}$ general Association of Polish Counties in 1999: "The self-government is a big school of the democracy. It teaches how to cooperate for the public weal while the differences are put aside. It instils in us first of all the respect and humbleness towards the decisions of the voters" (Przemównia, listy, wywiady Prezydenta Rzeczpospolitej Polskiej Aleksandra Kwaśniewskiego, 2000, p. 56). As a summary of the deliberations conducted here one could refer to a statement of the MP Robert Telus: "The civil society is born, however, there, at the bottom. Let's allow the civil society to be born (...)".

These grass-root initiatives bring the best effect, because then a man involves oneself into something which was invented by him, he puts his heart into it, dedicates his time and sacrifices himself into this initiative" (Sprawozdania stenograficzne z posiedzeń Sejmu $R P, 19.02 .2014)$.

\section{Conclusion}

In the Polish political thought after 1989, the self-government has been treated as an important element of ensuring civil security. This is due to several important reasons:

- the self-government is a barrier to the omnipotence of the state,

- it enables the direct participation of a citizen,

- it ensures the social security - this important issue is presented to a lesser extent in this article,

- it enables the building of civil society,

- it gives an opportunity to create new personal patterns,

A good summary of the deliberations carried out here may be a statement by the head of the Civil Institute Jarosław Makowski which can count on general approval: "Just as no one invented a better system than democracy, no one invented a more successful way of 
putting it into practice than self-governance (Makowski, 2014, p. 7). Marcin Król also said: "The hope for the maintenance and development of democracy lies primarily in local communities" (Król, 2014, p. 8).

\section{References}

Adamowicz, P. (2008). Gdańsk jako wyzwanie. Gdańsk: Słowo/Obraz Terytoria.

Bukowski, A. (2011). Demokracja lokalna a dobro wspólne. Uwagi sceptyka. Znak, No. 673.

Bokajło, W. (1998). Społeczeństwo obywatelskie. In Leksykon politologii. eds. A. Antoszewski, R. Herbut. Wrocław: Atla2.

Chruściak, R. (1997). Projekt Konstytucji PSL i UP. In Projekty Konstytucji 1993-1997, part 1. Warszawa: Wydawnictwo Sejmowe.

Ganowicz, E. (2014). Idea samorząaności w Polsce - próba aksjologicznej systematyzacji w ujęciu politologicznym. Przeglad Politologiczny, No. 2.

Gieorgica, P. (1991). Wybory a samorząd terytorialny. Wspólnota.

Górski, R. (2003). Demokracja uczestnicząca w samorządzie lokalnym. Poznań-Kraków.

Hartman, J. (2002). Nie-nowoczesny liberalizm. Projekt manifestu. "Przegląd Polityczny", No. 56.

Krzemiński, I. (2015). Liberalizm polski. Warsaw: SEDNO Wydawnictwo Akademickie.

Lipowicz, I. (2009). Ustrojowe aspekty reformy samorządowej w latach 1990-1998 w świetle współczesnych wyzwań wobec administracji publicznej. Ruch Prawniczy, Ekonomiczny i Socjologiczny, No. 2, p. $147-153$.

Imiołczyk, B., Regulski, J.(2007). Samorząd i demokracja lokalna. Raport konwersatorium Doświadczenie i Przyszłość, No 2.

Karnowska, D. (2011). Spór o wspólnoty. Idee komunitarystyczne we wspótczesnej polskiej myśli politycznej. Toruń: Wydawnictwo Adam Marszałek.

Kilmek, M. (2013). Samorzad terytorialny $w$ deklaracjach ideowych i praktyce politycznej Polskiego Stronnictwa Ludowego w III Rzeczypospolitej. Lublin: Wydawnictwo KUL. Koziełło, T. (2017). Myśl polityczna Ligi Polskich Rodzin. (2001-2009). Narodowa wizja państwa, społeczeństwa i polityki. Rzeszów: Wydawnictwo Uniwersytetu Rzeszowskiego.

Król, M. (2014) Stownik demokracji samorzadowej. Warsaw: Kurhaus Publishing.

Kulesza, M. (2008) Budowanie samorządu. Wybór tekstów ze "Wspólnoty”. Warsaw: Municipium.

Maj, E. (2004). Polska bez powiatów i regionów- ugrupowania neoendeckie wobec reform administracji publicznej. In Samorząd lokalny w Polsce. Spoleczno-polityczne aspekty funkcjonowania, edited by S. Michałowski, A. Pawłowska. Lublin: Wydawnictwo Uniwersytetu Marii Curie Skłodowskiej.

Makowski, J. (2014). Samorządność radykalna. Instytut Idei, No. 7.

Malewska-Szałygin, A. (2002). Wiedza potoczna o sprawach publicznych. Rozmowy o wtadzy lokalnej w wybranej gminie mazurskiej w latach 1994-1995. Warsaw: DiG. Mazowiecki, T. (2012). Rok 1989 i następne. Teksty wybrane i nowe. Warszawa: Prószyński i S-ka

Mażewski, L. (1989). Mechanizm rzadzenia w nowej konstytucji. Przegląd Polityczny, No. 12.

Nawratek, K. (2008). Miasto jako idea polityczna. Cracov: Korporacja Ha!Art.

Olszewski, P. (2007). Samorzad terytorialny w programach ugrupowań politycznych w Polsce (1989-1998). Toruń: Wydawnictwo Adam Marszałek.

Przemównia, listy, wywiady Prezydenta Rzeczpospolitej Polskiej Aleksandra Kwaśniewskiego. Wybór. 
(2000). Warszawa: Kancelaria Prezydenta RP. Radomski, G. (2017). Spory o samorzad terytorialny w polskiej myśli politycznej po 1989 roku. Toruń: Wydawnictwo Naukowe UMK. Rok rządu premiera Mazowieckiego. (1990). Zeszyty dokumentacyjne PAP, No. 6/271.

Sowa, M. (2011). Samorząd. Pięć kluczowych problemów. Znak, No. 3.

Sprawozdania stenograficzne z posiedzeń Sejmu RP. (19.02.2014). Wypowiedź posła Roberta Teleusa.

Stępień, J. (2015). Samorząd terytorialny w systemie władz publicznych i w społeczeństwie. In Rzeczpospolita w koncepcjach transformacji ustrojowej 1989 r., ed. A. Gołębiowska. Warsaw: Powszechne Wydawnictwo Prawnicze.

de Tocqueville, A. (1996). O demokracji w Ameryce. Warsaw: Fundacja Aletheia.

Taylor, Ch. (1994). Kiedy mówimy: społeczeństwo obywatelskie. In Europa i społeczeństwo obywatelskie. Rozmowy in Castel Gandolfo, ed. K. Michalski. Cracov: Znak.

Taylor, Ch. (1996). Polityka liberalna a sfera społeczna. In Spoteczeństwo liberalne. Rozmowy w Castel Gandolfo. Cracov: Znak.

\section{Author}

\section{Grzegorz Radomski}

gradom@umk.pl

Nicolaus Copernicus University in Toruń, Faculty of Political Sciences and International Studies; contact details: Powstanców 41, 09-200 Sierpc 
